\title{
Cyclic GMP-dependent protein kinase II promotes chondrocyte hypertrophy and skeletal growth
} Hiroshi Kawaguchi ${ }^{* 1}$, Hirotaka Chikuda ${ }^{1}$, Yosuke Kawasaki ${ }^{1}$ and Franz Hofmann ${ }^{2}$

Address: ${ }^{1}$ Department of Sensory \& Motor System Medicine, Faculty of Medicine, University of Tokyo, Tokyo113-8655, Japan and ${ }^{2}$ Technische Universität München, Biedersteiner Strasse 29, D-80802 Munich, Germany

Email: Hiroshi Kawaguchi* - kawaguchi-ort@h.u-tokyo.ac.jp

* Corresponding author

from 4th International Conference of cGMP Generators, Effectors and Therapeutic Implications

Regensburg, Germany. 19-21 June 2009

Published: II August 2009

BMC Pharmacology 2009, 9(Suppl I):S20 doi:10.1186/I47I-2210-9-SI-S20

This abstract is available from: http://www.biomedcentral.com/I47I-22 I0/9/SI/S20

(C) 2009 Kawaguchi et al; licensee BioMed Central Ltd.

Skeletal growth is achieved by endochondral ossification in the growth plate cartilage with orderly columnar arrays of resting, proliferative, and hypertrophic zones of chondrocytes. Cyclic GMP-dependent protein kinase II (cGKII) is a kinase that lies downstream of the C-type natriuretic peptide (CNP)/GC-B pathway which is essential for skeletal growth in both humans and rodents. We found that a naturally occurring mutant rat KMI that lacks the kinase domain of cGKII exhibits dwarfism due to the impaired hypertrophic differentiation of growth plate chondrocytes [1]. cGKII caused attenuation of the transcriptional function of Sox9, an inhibitor of chondrocyte hypertrophy, through inhibition of nuclear entry. However, inhibition of the nuclear entry was independent of the phosphorylation of Sox9 itself, suggesting that other phosphorylation targets of cGKII are important.

The cGKII-deficient (cGKII-/-) mice also showed dwarfism with an elongated growth plate due to impairment of chondrocyte hypertrophy [2]. A screen using a kinase substrate array identified glycogen synthase kinase-3 3 (GSK$3 \beta$ ) as a principal phosphorylation target of cGKII. Phosphorylation of GSK-3 $\beta$ caused its inhibition and this was associated with enhanced hypertrophic differentiation of cultured chondrocytes. cGKII-induced chondrocyte hypertrophy was suppressed by co-transfection with a phosphorylation-deficient mutant of GSK-3 $\beta$ at Ser9 (GSK-3 $\beta^{\mathrm{S} 9 \mathrm{~A}}$ ). Analyses of mice with compound deficien- cies in both protein kinases (cGKII-/-;GSK-3 $\beta+/-$ ) demonstrated that growth retardation and elongated growth plate caused by cGKII deficiency were partially alleviated by haploinsufficiency of GSK-3 $\beta$. cGKII and GSK-3 $\beta$ were

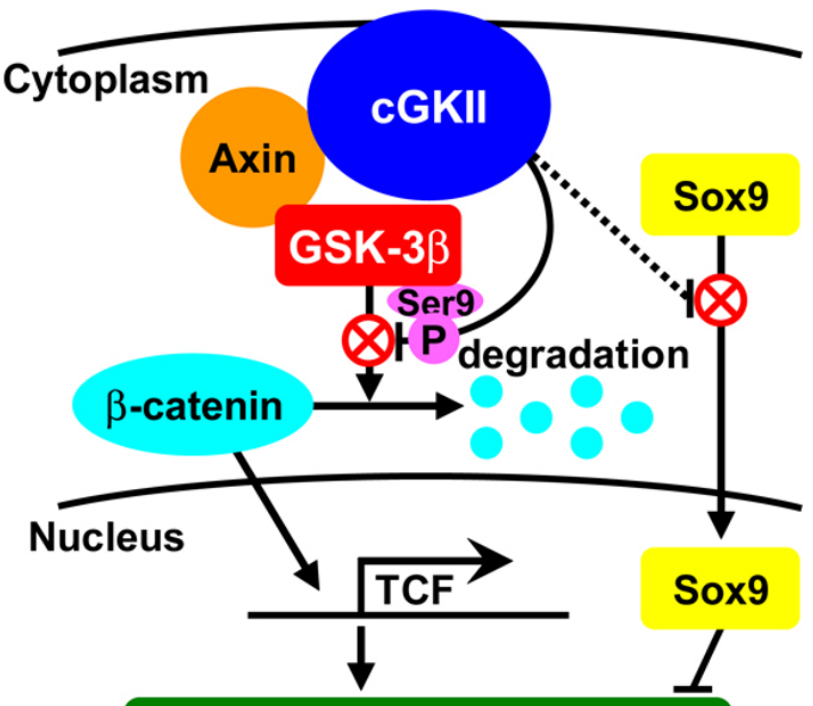

Chondrocyte hypertrophy 
co-localized in prehypertrophic chondrocytes of the growth plate with $\beta$-catenin, whose level was decreased in the cGKII-/- mice. Overexpression of cGKII increased the accumulation and transactivation function of $\beta$-catenin in ATDC5 cells, which were blocked by co-expression of GSK-3 $\beta^{\mathrm{S} 9 \mathrm{~A}}$. Figure 1.

\section{Conclusion}

Hypertrophic differentiation of growth plate chondrocytes during skeletal growth is promoted by Ser9 phosphorylation and inactivation of GSK-3 $\beta$, as well as the Sox9 transcriptional inhibition, by cGKII.

\section{References}

I. Chikuda H, Kugimiya F, Hoshi K, Ikeda T, Ogasawara T, Shimoaka T, Kawano H, Kamekura S, Tsuchida A, Yokoi N, Nakamura K, Komeda $\mathrm{K}$, Chung UI, Kawaguchi H: Cyclic GMP-dependent protein kinase II is a molecular switch from proliferation to hypertrophic differentiation of chondrocytes. Genes Dev 2004, 18:2418-2429.

2. Kawasaki $Y$, Kugimiya F, Chikuda $H$, Kamekura S, Ikeda T, Kawamura N, Saito T, Shinoda Y, Higashikawa A, Yano F, Ogasawara T, Ogata N, Hoshi K, Hofmann F, Woodgett JR, Nakamura K, Chung UI, Kawaguchi H: Phosphorylation of GSK-3 $\beta$ by cGMP-dependent protein kinase II promotes hypertrophic differentiation of murine chondrocytes. J Clin Invest 2008, I I 8:2506-25 I 5 .

Publish with Bio Med Central and every scientist can read your work free of charge

"BioMed Central will be the most significant development for disseminating the results of biomedical research in our lifetime. "

Sir Paul Nurse, Cancer Research UK

Your research papers will be:

- available free of charge to the entire biomedical community

- peer reviewed and published immediately upon acceptance

- cited in PubMed and archived on PubMed Central

- yours - you keep the copyright

Submit your manuscript here:

http://www.biomedcentral.com/info/publishing_adv.asp 